\title{
A tale of two fears: negotiating trust and neighborly relations in urbanizing Turkey
}

\author{
Jermaine S. Ma (iD) and Paul R. Hoard (iD)

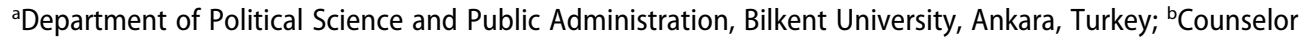 \\ Education Department, MidAmerica Nazarene University, Olathe, KS, USA
}

\begin{abstract}
Using a Turkish empirical case, we show how trust is negotiated among ruralto-urban migrant women as a result of their move from informal housing where they lived clustered with other migrant women, sharing their personal lives (arguably expressing and facilitating high trust), to apartment buildings where it requires life to be shared with a diverse group of residents (rural/ urban, religious sectarian, ethnic) and where they are expected to live individualistic lives. Given this socio-spatial transformation, we suggest trusting is understood and experienced by migrant women, as an on-going relational process of negotiating two competing fears to (1) not be alone; and (2) not be harmed by the people they risk/desire to be close to (physically and emotionally). This is significant for migrant women whose conservative values and way of life relies heavily on other women in close proximity to them (i.e. neighbors) for emotional and material support in the rhythm of daily life. This is further complicated by also needing to negotiate competing group identities - part and parcel to neighborly relations in polarized societies like Turkey. The process of trusting, we suggest, entails an on-going relational risk assessment/negotiation through knowing, visiting and sharing over time (in material and emotional ways).
\end{abstract}

\section{KEYWORDS}

Interpersonal trust; neighborly relations; Turkey; socio-spatial transformation; gender and space

\section{Introduction}

Contemporary Turkey, with its rapid growth, and increasing urban population resulting from an influx of rural-to-urban migration in the last half century has not only experienced a great deal of social change but also spatial change. As cities have expanded both in population and geographic area, various urban renewal projects have transformed these communities of informal/squatter (gecekondu ${ }^{1}$ ) homes into apartment complexes impacting rural-to-urban migrant women in the rhythm of their daily lives, and social relations in particular (Purcell 2017; Erman 1996). At the level of neighborly relations, this means that those who were different and socially distant are now brought physically closer, affecting the negotiation of social relations, and shaping one's understanding and experience of interpersonal trust between neighbors. This is significant, not only in light of persistent and historical sociocultural cleavages and 'Othering' in Turkish society (Kalaycıoğlu 2012; Çelik, Bilali, and lqbal 2017) but also in light of prior trust studies that have shown that '[s]ocial polarization in the form of inequality and ethnic diversity reduces trust' (Bjørnskov 2007, 1). These socio-spatial changes have continued to reinforce and perpetuate the tension between social groups and those considered the 'Other' complicating the daily rhythms of life for migrant women (Erder 1996; Çelik, Bilali, and Iqbal 2017; Erman 2011). In light of this transformation, we 
ask how is interpersonal trust understood and experienced in the rhythms of daily life and neighborly relations for rural-to-urban migrant women?

From the early days of trust research, as well as in response to various studies that utilize the trust concept, there is a general agreement among a wide range of scholars that trust is an important factor in the fabric of daily life. However, Turkey with consistently low levels of (generalized) trust (World Values Survey 2014) proves to be an anomaly among other countries, and might be considered one of the least 'trusty' societies in the world (Diez Medrano 2013), having 'almost no trust' (Delhey and Newton 2005). In general, according to the series of representative national values surveys conducted in Turkey since 1990, on average only one in ten persons answered affirmatively to being able to trust most people (Kalaycıoğlu 2012). As trust research has become increasingly more nuanced including looking at processes (Khodyakov 2007; Möllering 2013), context (Grimpe 2019), and relational approaches (Frederiksen 2014; Six, Nooteboom, and Hoogendoorn 2010), it has also enriched the broad strokes gained from large- $\mathrm{N}$ survey datasets. However, trust research that focuses on Turkey have been limited either to these broad strokes about trust (Kayaoğlu 2017), or to the realm of business relations of supervisors and subordinates (Wasti, Tan, and Erdil 2011). While these types of studies are insightful for better understanding trust in general (or at an organizational level) in Turkey, questions like how trust is understood and experienced (from a process perspective) in polarized and complex societies have yet to be addressed. As such, this study aims to fill the gap by providing an analysis of qualitative semi-structured interview data in order to bring a nuanced understanding of interpersonal trust in Turkey at the level of neighborhood relations, especially in light of its complex sociocultural and sociopolitical context, and its ensuing negotiation processes.

This research delves into understanding the intricacies of negotiating interpersonal trust among rural-to-urban migrant women in their neighborhoods in light of the aforementioned socio-spatial transformation and its consequences, particularly focusing on the sectarian religious tension between Alevis and Sunnis. We analyze 20 in-depth, semi-structured interviews with women who currently reside in neighborhoods in Mamak, Ankara and Ümraniye, Istanbul - two sites in which both rural-to-urban migration, with the building and subsequent (on-going) tearing down of gecekondu dwellings into apartment buildings and complexes have been well documented and studied (Erder 1996, 1999; Erman 1996, 2011). These two sites were chosen because this foundation enables a nuanced examination of the effects of spatial change and the sociocultural context on social relations.

In this article we argue that given the socio-spatial transformation of gecekondu neighborhoods, trust is understood and experienced by rural-to-urban migrant women, as an on-going relational process of negotiating two competing desires/fears (a form of risk) to (1) not be alone; and (2) not be harmed by the very people they risk/desire to be close to (physically and emotionally). This is significant for these migrant women whose conservative ways of life relies heavily on other women in close physical proximity to them (i.e. their neighbors) for emotional and material support in the daily rhythm of life (Erman and Hatiboğlu. 2018). This is further complicated by also needing to negotiate competing group identities, which is part and parcel to neighborly relations in urbanizing Turkey. We propose that the relational process of trusting entails an on-going assessment through knowing, visiting and sharing over time (in material and emotional ways).

\section{Women, space, and trust in neighborly relations}

Women as social agents in their communities are at the forefront of negotiating the changing boundaries of space and spatial concerns in social and neighborly relations, arguably including that of interpersonal trust (Purcell 2017; Mills 2007; Erman 1996). Scholars have noted the significance of place/space in social relations, the nature of those relations, as well as the interaction(s) between those spatial factors and social relations. DeCerteau, Giard and Mayol have shown that in urban neighborhoods, 'the system of relationships imposed by space' creates an internal tension for residents in managing the unpredictable boundaries between their private (i.e. anonymous) and 
public (i.e. visible) lives - '[when and where one encounters one's neighbors] is defined by chance comings and goings involving the necessities of everyday life' in various places within the neighborhood (de Certeau, Giard, and Mayol 1988, 15). This negotiation in urban neighborhoods is simultaneously the consequence of space and social relations; it is governed to a certain extent by a kind of 'propriety' that forms the boundaries of acceptable behavior within the community (de Certeau, Giard, and Mayol 1988; Mills 2007). This defines not only the space but also the nature of social relations in which 'each dweller adjusts to the general process of recognition by conceding a part of himself or herself to the jurisdiction of the other' (de Certeau, Giard, and Mayol 1988). Choosing to live within the boundaries of a neighborhood comes with a tacit acceptance that the 'neighborhood imposes' on each resident 'a savoir faire of simultaneously undecidable and inevitable coexistence' (de Certeau, Giard, and Mayol 1988, 15, emphasis in original).

Mills' research in an Istanbul neighborhood (mahalle) observes that '[t]he closeness of mahalle life, while it creates a space of safety and familiarity, also includes the potential for a negative neighbor to abuse the connected neighborhood space and violate delicate norms by spreading private information or manipulating others' (Mills 2007, 344). Furthermore, recognizing the specific sociocultural and sociopolitical contextual nuances, not only of a neighborhood, but the actions, consequences, and patterns of women in the Turkish mahalle context is necessary to tease out the nuances of neighborly relations. Mills also highlights the gendered nature of neighboring among Turkish women, suggesting there is a 'cultural value of preferring to be with people over being alone' (Mills 2007, 341). This suggests a contextual nuance in the negotiation of social relations, including interpersonal trust. Mills and Purcell note that for certain women in Turkey - especially stay-at-home moms and housewives - the specific locality of the home is a woman's main domain of influence where visiting and participating with women in the neighborhood predominately takes place (Mills 2007; Purcell 2017). Purcell argues that viewing the home as 'an important means whereby women position themselves in relation to one another in an urban context marked by novel forms of social heterogeneity' (Purcell 2017, 31). In Urfa (Southeast Turkey), moving from rural-to-urban contexts Purcell found, 'a certain thickening of the boundaries of the home, and an increasing emphasis on the interiority of the home vis-à-vis the world outside' (Purcell 2017, 31). She recognized that 'urban life increases [their] "mobility" in some respects,' yet it 'paradoxically entails a broader separation of women "at home" from various social others such as extended family, neighbors, guests, strangers, and men' (Purcell 2017, 31).

For migrant women, neighbors play a significant role, especially for those who lived in gecekondu settlements. Erman notes that for these Anatolian women in particular, 'intimate social relations with neighbors ... made gecekondu areas attractive' as they 'spent a great deal of their time in the neighborhood and their relations with the rest of the city were limited' (Erman 1997, 95). Moreover, the spatial clustering of gecekondu homes created convenient spaces where women 'easily gathered inside or in front of houses' (Erman 1997, 95). This resulted not only in a camaraderie (of being known, respected and loved), a common history, and the ability to observe their neighbors' behavior and character in natural ways, but it also served as a means where recent migrants 'did not feel lonely in the presence of their neighbors [with whom they] spent their time' (Erman 1997, 95). This spatial arrangement enabled gecekondu women residents to facilitate the assessment and expression of trust among neighbors. For Anatolian migrants who value conservative and community-oriented ways of life that resembled their past village lives, gecekondu living provided a safe environment for women (of all ages), where women had the freedom to interact with their fellow (women) gecekondu neighbors (Erman 1997; Erman and Hatiboğlu. 2018). With the change in their living environments from gecekondu-clustered neighborhoods to apartment complexes, also came with adjustments to how and where neighbors related to each other. The loss of common outside spaces between gecekondu homes were replaced by '[t]he private spaces of the home' along with some women 'reappropriating the public spaces inside [the apartment complexes], sitting outdoors with neighbors and carrying out "gecekondu activities" on the sidewalks, in the [apartment] block gardens, and around the [apartment] blocks' in order to '[fight] against their isolation inside their apartments' 
(Erman and Hatiboğlu. 2018, 822). Together, these socio-spatial factors (and changes) beg the question: what does the negotiation of physical and relational space entail for rural-to-urban migrant women in Turkish neighborhoods, especially as it relates to trust?

In trust studies, women have often been shown to have lower levels of trust in comparison to their male counterparts (Kayaoğlu 2017). As such, focusing on women not only allows for focusing on the social agents in Turkish communities but also provides a baseline examination of trust in context. At the neighborhood level, focusing on neighborly relations between women creates the ability to examine every day (social) interactions and the negotiation of gender in space (Mills 2007; Purcell 2017) in light of Othering (Çelik, Bilali, and lqbal 2017), as well as within the boundaries of the home - where some women have shown to 'formulate their aspirations for upward mobility, and establish social distance along the axes of class and ethnicity' (Purcell 2017, 31).

Within the discussion surrounding trust, and all its variants in the literature (political trust, institutional trust, system trust, etc.), this study focuses on interpersonal trust - namely trust between people (Frederiksen 2014). This concept has been observed in the greater trust literature as an on-going relational (Frederiksen 2014) process (Khodyakov 2007; Six, Nooteboom, and Hoogendoorn 2010; Möllering 2013) of risk (Luhmann 2000), and a form of vulnerability (McEvily 2011), in light of knowledge (Hardin 2006). As the body of trust research grows, more nuanced discussions about trust, including the subtle yet significant distinction between conceptualizing trust (as a noun) versus trusting (as a verb) (Möllering 2013) has emerged. While the noun form of the concept is useful in some aspects, it has the unintended consequences of giving the impression that trust is a fixed constant. Analyzing trust or trusting as a process opens the door to more nuanced analyses of the complex socio-spatial factors in play (Möllering 2013; Grimpe 2019). Furthermore, although there is a plethora of trust literature, agreeing on concepts is one area in which trust research is growing, especially in recent years (Miller and Mitamura 2003; Nannestad 2008). While there are studies on trust as a process (Khodyakov 2007), the question remains what do we mean by process? One such contribution in helping to bring some structure to this conversation is Möllering's (2013) framework on trust processes. In line with trust scholars like Frederiksen (2014), Grimpe (2019), and Möllering (2013) we recognize the relational, contextual and process-oriented nature of trust, and this study aims to build upon their contributions.

Given the inductive nature of this study, we further discuss our definition of trust - namely, how our respondents understood and experienced trust. Briefly, we define interpersonal trust as a locally embedded relational negotiation process of being willing to be vulnerable to another given what is known (a form of risk). We propose that trust for these rural-to-urban migrant women is, what we call, a gendered relational negotiation process/iterative practice, as respondents frequently described how trust was built only after multiple experiences of trustworthy behavior over time.

\section{Urbanizing Turkey and the context of rural-to-urban migrants}

When speaking of 'urbanizing' Turkey, we specifically focus on the transformation of space from gecekondu dwellings into apartment complexes. In both sites, there are still gecekondu dwellings, as all of them have not yet been transformed into apartment complexes for different reasons. The descriptor, 'urbanizing' is intentional as it hints at the continuation of urbanization in current day Turkey. Thus, the influx of rural-to-urban (chain) migration starting from the 1950s, peaking in the 1980s (Erman 2011) is utilized as the primary lens through which to understand how a specific segment of Turkish society experiences interpersonal trust. Through various mechanisms of increased job opportunities in the city, the building of gecekondu houses in the city's periphery, chain migration from Anatolian villages and rural areas within Turkey, and the subsequent forming of communities, rural migrants somewhat succeeded to keep themselves physically distant from the Other. However, over time, as cities grew, gecekondu areas that were on the outskirts of the city became more heterogeneous settlements within the city. In cities like Istanbul, the population surge was not only felt in numbers but also relationally. Over time communities were established but it was not without its conflict and tension between urbanites - those who were living in the city prior - and recent migrants (Erman 2011; Erder 1999). 
Eventually, as larger cities continued to grow and expand into the outskirts, these gecekondu neighborhoods and communities became incorporated into the municipality, initiating the building of apartment complexes in certain areas (Kuyucu and Ünsal. 2010). As such, efforts were made to demolish gecekondu areas and gentrify them into more organized development. ${ }^{2}$ Despite these similarities, it is important to note that Mamak and Ümraniye's geographical location in relation not only to their respective city centers but also their position with respect to their city's growth and expansion, resulted in varying speeds of transformation. Ümraniye, located on the Asian side of Istanbul, became prime real estate as Istanbul expanded, and continues to have new development. Yet Mamak, located in the outskirts of Ankara, remained untouched by private developers until the 2010s (Poyraz 2011). Even though Ankara expanded and grew (and is the second largest city in Turkey, behind Istanbul), its direction of growth was not towards Mamak; only in the last decade have there been more urbanization projects in Mamak (Erdoğan 2015).

The varying speeds of development also affect the residents' experience and familiarity levels of gecekondu living. Those in Ümraniye are less likely to have first-hand experience living in gecekondu homes, whereas most of the Mamak residents would have recently moved from gecekondu dwellings into apartment complexes. In other words, for the majority of current day Mamak residents the changing process of their living spaces (gecekondu to apartment buildings) were a part of their own life experiences as a kind of 'first generation' apartment dweller, while for a majority of current Ümraniye residents, already constructed apartment buildings were the spatial arrangement available.

Social group tension, namely the (historical ebbs and flows of) polarization between and among groups, and the various identity allegiances have been, and continue to be a prevalent part of Turkish society and politics in contemporary Turkey (Kalaycıoğlu 2012; Çelik, Bilali, and lqbal 2017; Shankland 2012). In the literature, this negotiation and contestation of identity within sociocultural cleavages (Kalaycıoğlu 2012) and the fault lines they produced are discussed in relation to Othering (Çelik, Bilali, and Iqbal 2017). As Çelik et al. discuss, 'Othering is a process of identity formation in which a group identity is constructed vis-à-vis an Other, that is often perceived as threatening' (Çelik, Bilali, and lqbal 2017, 222). In the current Turkish context, there are three salient sociocultural cleavages that can be addressed (and ought to be addressed separately as they each have their own nuances). For the sake of space and clarity, we focus on one of these cleavages as an initial example of how trust in neighborly relations is navigated at the neighborhood level among rural-tourban migrant women who identify with competing group identities: namely, the religious sectarian fault line between Alevis and Sunnis (Çelik, Bilali, and lqbal 2017; Shankland 2012; Poyraz 2005).

In Turkey, where (Sunni) Islam is the predominant religion, Alevis are estimated to make up somewhere between $10 \%$ and $25 \%$ (upwards to 14 million) of Turkey's current population and are considered a non-Sunni religious community (Shankland 2012; Poyraz 2005; Bardakçi 2015; Öktem 2008). Since their liberal beliefs and practices stem from a different school of law in (i.e. interpretation of) Islam, they are viewed as 'a heterodox and non-conformist Islamic community' which supports 'the rival Shiite Turco-Persian Safavid state' with different religious and social practices (Bardakçi 2015, 351).

Alevis in Turkey since Sunni Ottoman rule from the $16^{\text {th }}$ century, have been subjected to persecution, and unsurprisingly have been in support of Mustafa Kemal and the establishment of a secular Republic since the 1920 s 'in the hope that the new state would be at an equal distance from all belief systems and would bring Sunnism under control' (Bardakçi 2015, 351). From the late 1970s and as recent as 2013 there have been various incidents of violence and discrimination committed against the minority Alevi population (Çelik, Bilali, and lqbal 2017; Bardakçi 2015). For Alevis discrimination is felt by others in society, and through various legislation decisions by the state. Although recently Alevis have been recognized in their social, religious and political identities, it has felt more like apathy than full acceptance (Bardakçi 2015). While these are only cursory highlights of the complexities the Alevi community has experienced - there are also intricacies ${ }^{3}$ found within their community - it is important to note that all together, Alevis have a 'long memory of ... discrimination and suffering' at both the societal/social and political/policy level (Öktem 2008, 7). 
As the following sections will show, without an understanding of these contextual complexities and nuances, it would be difficult to see the significance of how and why neighbors in this study relate to each other in the ways they do, and how they understand and experience trust.

\section{Research methods}

Twenty in-depth, semi-structured interviews ${ }^{4}$ were conducted starting with two pilot interviews in 2014. The bulk of the data was collected during 2016-2017 after the failed (attempted)-coup of July 2016, which changed the political climate, and hence required a revision of the interview questions. There were certain questions that were no longer safe to ask, or rather, if asked directly would result in non-answers, or answers that were politically 'safe' given the government's declared state of emergency, and thousands losing their jobs. Consequently, in 2016 two more pilot interviews were conducted, and the questions were further refined.

All of the (30 min-2 hour) interviews were conducted in Turkish, digitally recorded, and transcribed. In each interview, every question was asked but the respondents' cues were followed in terms of how far to take the questions. Sometimes this meant asking follow-up questions, at other times it meant leaving their answers as the final answer. Respondents were allowed to express themselves freely without external pressure to answer in any particular way. Respondents were asked open-ended, nonleading questions, and follow-up questions using similar words and concepts utilized in their answers. After each interview, the primary researcher kept a research journal of thoughts and experiences, making note of things that might not have been caught on the audio recording. The twenty plus interview questions revolved around the subject of trust, in order to uncover how trust is understood and experienced. For example, In Turkey is it important to trust? In your opinion what is trust? What three words come to mind when you think of trust? Who do you trust and why? Do you trust your neighbors, family, those in your neighborhood, district, and/or city? Can you share about how you began to trust someone? What caused you to stop trusting someone? What would make it possible to trust them again? The respondents' answers, and emerging themes from their answers formed the basis of our findings. All of the respondents in Mamak, Ankara and Ümraniye, Istanbul were people we were not acquainted with prior to the interviews but were contacts of the primary researcher's friends/ supervisors. Therefore, in each interview, we established relations of trust by proxy.

We reflexively interpreted the responses of the respondents through our experience as foreigners living, and researching in Turkey for over a decade. While this reflexivity simultaneously affords the ability to view this as an outsider/foreigner, it also limits one's ability to have the level of 'insider knowledge' that one would have if they were Turkish. This kind of reflexivity has its limitations as well as its benefits (Ergun and Erdemir 2010; Karakayali 2004), and we acknowledge these openly.

\section{A tale of two fears: 'you have to trust in something or ... you're forced to live all alone.'}

In light of the socio-spatial transformation of rural-to-urban migrant women's living spaces and social group tension(s) present in current day Turkey, we argue that our respondents understand and experience trust as a relational process of negotiating two competing desires: their desire for relationship, but also their desire to not be harmed. Our analysis shows two things worth highlighting: first, trust for our respondents is a locally embedded relational negotiation process of holding these two desires/fears in tension. And second, trust is performed as a gendered negotiation process of being willing to be vulnerable to another given what is known through sharing, visiting and knowing.

We interpreted our respondents' answers and suggest that trust for them is a relational process of negotiating two fears in tension. First, is the fear of loneliness, or the desire for relationship with others so as not to be left alone. This desire provides the motivation to engage in trust-building and be willing to be vulnerable in developing relationships. Menekşe, a resident in Ümraniye explained: 
'You have to trust in something ... or else the other option is you are forced to live [in society] all alone .... [Y]ou need to be willing to trust others. Everything is a bit reciprocal: you are willing to trust another so that the other person in turn trusts you ...'

Menekşe's response not only echoes Mills (2007) finding in another Istanbul neighborhood that there is a cultural value of preferring to be with others than to be alone, but also that Menekşe connects the concept of trust, and the necessity of trusting others in order not to be alone. Songül, a resident in Mamak, had a similar response to Menekşe's with respect to the value of neighbors especially to help quell loneliness while highlighting the distinction of how she determines whether or not to trust them: 'If the neighbor is good, it's an important thing. I think [living] without neighbors is impossible because you're under the same roof.' She continues:

'I only trust one of [my neighbors]. With that [trusted] neighbor I freely come and go, and comfortably visit her home, I don't go knocking on every one of [my neighbors'] doors, visiting them. But if someone comes to my door I open my heart to them, and do all that I can to perform my [neighborly] duty. I am not going every minute to [all my neighbors], I only go to one [neighbor I trust]. You can't be close (samimi) to all of them ...'

Songül not only makes a distinction between those whom she trusts and those she only greets but she elaborates on a specific locality in which trusting takes place. She also distinguishes between whose home she enters, and whom she welcomes into her hers. These specific intersections of space and social relations (i.e. one's home) are not only directly related (Mills 2007; Erman and Hatiboğlu. 2018), but are a part of distinguishing where, when and whom to welcome in; one willingly welcomes another into (certain) spaces when they feel safe. Entering a home (or being invited into a home of another) could represent a particular locality of negotiating trust.

These answers led us to uncover the decision-making process towards trusting. Being able to trust another is not a simple process, especially in light of the aforementioned social-spatial factors and nuances. Before our respondents reported arriving at this place of trusting their neighbors, they needed to know (tanımak) them. In fact, a common response to the interview question 'In general, do you trust others?' was 'I don't know them (tanımıyorum). How could I trust them?' Specifically, they wanted to know and be (relationally) familiar enough with them for two reasons: (1) predictability; and (2) to get to know their neighbor's character. It seems that knowing another helps one predict how neighbors may react in certain situations, which is another data point in the trusting process. Menekşe clarified what she meant by trust with a nuance of predictability, namely those she trusts tend to be like her: 'Someone that thinks like me, like in a situation we would more or less have the same type of reaction, you know as if we had the same mind - that person can be trusted... [that] is someone I can trust.'

One way to reduce the risk of harm in relationships is through the process of gathering information about a neighbor's character over time. In their gecekondu days, this process was faster and natural given the common spaces afforded by their living arrangements, and several Mamak respondents commented how missed those days and spaces. In contrast, when Canan, an Alevi residing in Ümraniye, was asked how many neighbors she trusts in her building, she shared the same selective view with another qualifier: '[l trust] only my neighbor across the hall.' She continued, 'it's important for me that they [who are trustworthy] are honest (dürüst), sincere (samimi), and genuine from the heart (içten). In the end, empathy is important and for you to see the person as yourself.' Songül and Canan's responses hint at specific character traits with respect to trust: the notion of intimacy, sincerity, and closeness (being samimi). In response to how Songül knows that someone is samimi, she replied very matter-of-factly:

'For example, ... [o]nce you have several interactions [with them] then you can observe and see that that person stands near you [in their lifestyle and values]. If you don't feel an impropriety (kötülük) [i.e. a type of harm, including gossiping], you get closer. If you do, you put some distance [between you and them].'

The significance of this 'knowledge,' we suggest, is to be able to identify those who would not cause harm. Most if not all the respondents differentiated between those who would harm them, and those 
who would not harm them as one of the distinguishing factors of what it meant to be a 'good neighbor,' no matter what their (religious sectarian or ethnic) background might be. Songül stated:

'Since I've moved to this flat, [one of our upstairs neighbors] is Kurdish and we've been like a family. She is so sincere (samimi) that I once gave her my keys [to my flat] because something came up one night. She would do the same if something came up for her. Whether it's an errand or illness, we would be there for each other ... [W] hether it concerns my husband, or children, we ought to all be us together. We [Alevis] don't discriminate, we just look at people as people, and if others treat me as a person ...

Our results showed that the process of information gathering entailed specific (repeated) gendered neighborly practice(s) by our respondents. Canan noted that trusting her neighbor across the hall came with time 'by sharing things [with each other].' When visiting one's neighbors, it usually includes chatting about and sharing in the daily/mundane stuff of life - a gendered practice in neighborly relations among women in Anatolian Turkey (Mills 2007). Sılam, an Alevi resident in Mamak mentioned that when her neighbors gather, they

\footnotetext{
'sit and talk about their children, womanhood, and saving [money]. For example I explain how "I value the money that comes to me" ... And as Anatolian people, we talk about dowries for our daughters when they get married, and how we want to help them set up their [new] homes. You know, [Fatma, my trusted neighbor,] and I, [get] together and talk about what we bought [for their houses] ... You know everyday, daily stuff, we don't gossip; I don't criticize my neighbors and they don't criticize me.'
}

It should be noted that Silam makes a subtle but significant distinction in what is welcomed as a part of communal living (e.g. talking about their children, womanhood, etc.) and what is not (e.g. gossiping, criticism). Likewise, the kind of neighborliness Menekşe values and yearns for is where you can go to someone in the same building for help. Menekşe noted that going to her neighbors for help is a joyful necessity. Menekşe explained, 'even if [l'm] bored, in two minutes [I] can go and knock on [my neighbor's] door and say "hello! What are you up to?" I enjoy getting fresh air in this way.' She shared an instance where one rainy morning she ran out of bread [for breakfast (a staple for that meal)].

'If I didn't have a neighbor ... I [would've] needed to go out again, change my clothes, and go buy bread. And that would've been all for ... bread, a simple problem. That is an example of neighborliness, you see it's something simple, but I really love [this kind of] neighborliness.'

This is significant in apartment living for women who are near their homes all day; their neighbors have a significant role in the rhythm of their daily lives. They are not just neighbors, but people with whom they share their lives, families, and food. Sılam made an even more stark statement in saying:

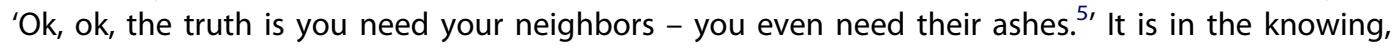
visiting, and sharing of life that one's loneliness is also simultaneously quelled.

Additionally, our respondents explained that it is in the relational process of visiting, sharing and getting to know their neighbors that they are able to differentiate between trustworthy neighbors and untrustworthy neighbors. Gülizar and her daughter Raziye in their joint interview shared, 'You learn by engaging in neighborly relations, and coming and going to your neighbors'. If any harm comes [my way], I won't meet with them [again]. But if harm doesn't come to me, I can [keep] seeing and visiting with them.' Raziye, continued, 'You learn [what kind of people they are] from their actions, conversations, and their reactions.' Gülizar agreed, 'So, you talk with [your neighbors] and then you see: do they gossip behind your back? Do they argue with you? Do they harm you? [If they do], you can't continue to engage in neighborly relations with them.' Mentioning gossiping is not only significant but it is another example of a gendered type of harm. The notion of gossip within the neighborhood context carries the functions of 'a kind of policing' of others' behavior while 'visiting with neighbors' and 'sharing of information [and observations] between women in continual visiting' (Mills 2007, 343). Herein lies the distinction between harm (gossip) and familiarity/being close (samimi). One is a welcomed benefit of communal living, as an expression of familiarity, and the other is experienced as a hurtful, personally manipulative type of harm - an unwelcomed consequence that also comes with the territory of neighborhood life. In this way, gossip can be understood 
as a type of 'practical behavior of "miniscule repression"' (de Certeau, Giard, and Mayol 1988) that residents in a neighborhood recognize and perhaps (at best) reluctantly concede to as a potential consequence of the closeness of mahalle life in Turkey (Mills 2007). This dual potential of harm and support is at the core of the relational risk process in neighborly relations among women as they do life together in visiting, sharing, and knowing. While this possibility of harm also existed in their gecekondu days, the transformation of their living arrangement also changed the natural and quick nature of assessing their neighbors' character.

This leads us to the second fear - being harmed - in considering the relational negotiation process of trusting (that is held in tension with the first fear - being alone). For the respondents in both Ümraniye and Mamak the fear of being harmed in general is a present reality in urban neighborhood living, but being harmed by those who are different than them (i.e. the Other) presents a greater possibility of a perceived threat.

Our respondents had varying experiences with their neighbors. Some had positive experiences of not being harmed (Gülizar), and others had negative experiences of being harmed (Sılam) in light of the tensions between social groups in Turkey are reinforced and perpetuated. Gülizar (in her 80s), one of the oldest respondents, a Sunni in Istanbul demonstrated this powerful aspect of trust as a negotiation of these fears when reflecting on the past: 'I lived among Alevis for 30 years. [But,] I didn't experience harm in the 30 years in the same building, we still see (and visit) each other ... [T] hey really love me and my late husband.' In fact, she explained that she still goes and visits with them even though she moved from that neighborhood ten years ago (to be closer to her daughter who divorced, so as not to leave her [daughter] alone), continuing their (neighborly) relationship even from afar. When Gülizar and her family opted to move into this apartment building, her friends warned her 'all the people in the apartments are Alevi.' She laughed as she recalled:

'I had no idea what Alevism (Alevilik) was [at that time]. But ... in time, I got to know them. Among the Alevis, they don't look at you with evil intent at all, they don't dare leer at you, their men are honorable (namuslu).'

Around the time ( the 1970s) when Gülizar and her family moved into the apartment building, Alevis were a somewhat known but small minority in society. It wasn't until the 1990s when identity politics became more salient in Turkish society, and in turn, the Alevi identity became more visible (Poyraz 2005). But Gülizar is a part of the majority, namely of the Sunni population. So even though Gülizar, as a Sunni, and her family were the 'minorities' in a majority Alevi area, she and her family in the greater population of the city and country were actually a part of the majority. Although Gülizar and her family were the Other to the Alevis, they may not have felt Othered by their Alevi neighbors. As this highlights, both the changes in the city's demographic makeup, and spatial arrangement allowed the opportunity to live in close proximity with those who are different - both a potential position of vulnerability, and increased fear where living next to the 'Other' could potentially increase being harmed. This also hints at the locally embedded process of neighborly relations among women (which could potentially lead to trust). The relational interactions between members of different social groups in each other's homes serve as a mechanism in neighborly relations to help navigate the potential perceived threat by allowing relationships to develop on their terms, especially since the functionality of gecekondu common spaces are no longer a reality. To the extent that Gülizar didn't experience harm, she was open to keep moving towards trust, and closeness, through visiting and knowing her neighbors of a different identity group.

Alternatively, Silam, an Alevi, experienced how this relational process (and the quantity of contact) does not always lead to trust when harm is sensed. Silam's Sunni neighbor refused her invitations to come to her house and in turn, never reciprocated the invitation. This meant there was no way to get to know her, and the mechanism that could lead to trust was hindered. By not accepting Silam's invitation - an act of vulnerability and openness on the part of Silam - she stymied one of the main ways to get to know her neighbor. Notably, by not providing a valid reason for not being able to come over, she effectively distanced herself from Silam, perpetuating the normative tension felt between religious sectarian groups in Turkey. This type of harm perpetuates a deep-seated hurt between Alevis and Sunnis, where Alevis 
often feel harm in the subtle forms of discrimination and rejection as the minority religious sectarian group in Turkey (Çelik, Bilali, and Iqbal 2017; Öktem 2008). Sılam is kind and says hello when they pass in the hallways, but noticed that these particular (Sunni) neighbors do their best to avoid eye contact with her, and don't even respond when she greets them in the hallway. Moreover, as Menekşe mentioned above, in order for a (neighborly) relationship to progress there must be mutuality and reciprocity. This reciprocity (despite contact) is unfortunately something that Silam did not experience with her Sunni neighbor. It is the continued and cumulative effects of (positive and negative) interactions like these that are a part of gathering of information that leads to either the building up or wearing down of one's willingness to keep risking in relationship with others. Again the focus here is not on one particular point in time (i.e. viewing trust as a noun), but the process of trusting (i.e. viewing trust as a verb) (Möllering 2013; Grimpe 2019).

\section{Trusting as a gendered relational negotiation process of being willing to be vulnerable}

Focusing on the neighborly relations of our respondents, we argue that the socio-spatial changes especially in light of existing social group tensions, and their consequences the respondents experienced shape how they understand and experience trust, namely as a gendered relational negotiation process. We highlight that contextual factors challenge the perceived safety of rural-tourban migrant women, making them (and the generations that follow) more vulnerable to being harmed by the (real or 'imagined') Other. This resulted in trusting being far more complex and nuanced; as our respondents noted, trusting others who are similar (to them) is far simpler and straightforward. Those who were potentially different and distant (relationally and spatially) are now brought physically closer. However, as the respondents also noted both explicitly and implicitly, this fear of the Other runs in tension to the felt need of being in relationship. Therefore, we suggest that trusting becomes this gendered relational negotiation process of holding in tension the desire not to be alone with the desire not to be harmed when the Other is now closer than ever before, and potentially your neighbor in your apartment building.

Given what is discussed above, simply stated, the relational process of trusting for our rural-tourban migrant respondents is a risk. Specifically, it entails an on-going risk process of willing to be vulnerable to one's neighbor (based on what is known and experienced with them). We suggest that the women in this study experienced and understood trusting as a relational negotiation process that entails an iterative practice of not only gathering information (through knowing, visiting and sharing with their neighbors), but also utilizing that information in either risking greater vulnerability (i.e. trusting), or not. We call it an 'iterative practice' because the negotiation process of our respondents was not a one-time event, rather an on-going (iterative) practice of gathering and mutually exchanging information through lived relational experiences (Möllering 2013). When respondents talked about trusting those they know it connotes a risk-taking experiential level of familiarity and not just intellectual knowledge ${ }^{6}$ about a person. It is about being known, but also involves a greater risk of potential harm by the one who knows you (de Certeau, Giard, and Mayol 1988; Mills 2007). In fact, these 'risks' and practices can be simple as saying hello in the hallways to gauge a neighbors' openness as in the case of Silam, and/or in the sharing of food, and asking one's neighbor for necessary ingredients as seen with Menekşe. In fact, Menekşe said that she prefers going to her neighbors for ingredients rather than running to a nearby market. Only if there weren't a trusted neighbor in her building, would she go and pay for what was needed rather than ask a neighbor. Here we see a conditional willingness to be vulnerable in asking for help and/or acknowledging a problem given what is known of one's neighbor's character - based on the extent to which they are familiar with them, and the quality of their contact.

However, it is also clear that while our respondents value neighborly relations, there is an important difference between appreciating neighborly relations and trusting their neighbors. This underlines the dualistic nature of the negotiation process in holding two fears (or desires) in tension: the desire for relationships must be tempered by the fear of harm, and vice versa. When Menekşe 
was asked if she trusted her neighbors, even after waxing eloquent about the importance of neighborly relations, and how much she loves neighborliness she responded that she only trusts a few of her neighbors. Similarly Canan and Songül express similar sentiments. This highlights the distinction in many respondents' conception of trusting from neighborliness and kind neighborly duty - which might in fact be an offshoot of a high value for hospitality in Turkish culture.

This points to our suggestion that trusting is not only locally embedded within the neighborly context, but that these particular gendered ways of doing neighborly relations are also salient in the building up and breaking down of trust relations. One important way it is developed is through the on-going, relational iterative process of knowing, visiting and sharing over time - which is a gendered practice previously seen in another study (Mills 2007). This type of knowing, visiting and sharing over time is a specific mechanism used by women within their neighborly relations. This was perhaps most notably seen in the example of Silam, whose village days are not far from her, but who has seen drastic changes in the demographic makeup of her neighborhood and living arrangement. This creates a context in which she chooses to engage in an iterative process of trust building delicately. Furthermore, it highlights the specific site of the home where relational interactions take place between neighbors. The home, and perhaps more specifically passing through/being invited in past the threshold of the home's entryway can be seen as the beginning of when, and where one is willing to risk and enter (physically and relationally) into the negotiation process of trusting.

On the other hand, this can be contrasted with Gülizar's 30-year experience with living among her Alevi neighbors, with whom she came to love and trust in time after multiple experiences of trustworthy behavior by her Alevi neighbors. For Gülizar and her Alevi neighbors, their longlasting neighborly relationship, ultimately led to an instance where the normative group tension/ fault line between Alevis and Sunnis were bridged over time. This also demonstrates empirically what Frederiksen showed theoretically about the on-going relational process of trusting: 'Trusting is an ephemeral characteristic of a process which merges past and present, conceiving and being, action and becoming, and alignment and aligning' (Frederiksen 2014, 182). Again, we suggest the salience of trusting as an iterative process of mutual knowing, sharing, and visiting over time (Möllering 2013; Six, Nooteboom, and Hoogendoorn 2010; Grimpe 2019).

\section{Conclusion}

In order to comprehend how interpersonal trust is understood and experienced as a negotiation process, it is essential to first recognize and examine the context and space in which it takes place. In this particular Turkish case, the phenomenon of rural-to-urban chain migration, socio-spatial transformation, along with deep-seated sociocultural/group tensions and polarization shaped the context of the women in this study. As such, for these women, we show that the process of trusting not only takes time but is a nuanced gendered relational negotiation/iterative practice of holding two fears (or desires) in tension: the fear of being alone, and the fear of being harmed. We demonstrate that for our respondents over time, in living and sharing in the daily, mundane stuff of life, salient sociocultural cleavages have the possibility of being bridged, but only to the extent that neighbors (of different groups and identities) engage willingly in the iterative practice of knowing, visiting and sharing in each other's homes (a type of on-going risk in both material and emotional ways). We also demonstrate that for migrant women, the home becomes a significant site of trusting. These contextual factors viewed together allow for a more nuanced understanding of the process of trust in Turkey (which incorporates the negotiation of physical and relational space) for this segment of Turkish society. This deeper understanding can help move us closer to exploring important questions such as why trust in Turkey is consistently surveyed as being low, and what steps could be taken in order to enhance the relational process of trusting, especially in highly polarized societies like Turkey. 


\section{Notes}

1. In Turkish gecekondu literally means: 'settled at night.' These squatter homes were built by rural-to-urban migrants in the cities' outskirts. Henceforth, we use the term gecekondu to describe this type of informal housing.

2. All of the respondents in this study were residents in apartment complexes built by private developers; this paper does not address state-driven development.

3. For a comprehensive look at Alevi relationships with the Turkish state, and the various ideological points of departure among Alevis see Bardakçi (2015).

4. Informed consent was obtained from all participants in the study; their names have been changed in order to protect their identities. The primary researcher's university's ethics committee also approved the interview questions.

5. The Turkish proverb ('komşu komşunun külüne muhtaçtır') expresses the necessity of neighbors and how neighbors are always there to help each other with anything. (Literally: 'A neighbor needs their neighbors' ash.').

6. In Turkish, there are two verbs associated with knowing (tanımak - to know/be familiar with/to recognize; and bilmek - to know intellectually about something). The verb consistently used by our respondents was tanımak, which inextricably is tied to having a (direct or indirect) relationship.

\section{Acknowledgments}

We would like to thank Dr. Tahire Erman, Dr. Aylin Topal, Dr. Meral Uğur Çınar, Petra Cafnik Uludağ, Julinda Hoxha, Christina Hamer, Bonnie Erdem, Dr. Elisabeth Özdalga, and Michelle Kim for their helpful comments and encouragement throughout this process. We are grateful to the women who graciously shared their stories, to Lauren and Betül whose adept transcription skills were invaluable to the analysis process, and to the two anonymous referees whose comments and critiques were vital in helping us further develop this article.

\section{Disclosure statement}

No potential conflict of interest was reported by the authors. This article is part of Jermaine Ma's PhD dissertation research conducted at Bilkent University.

\section{Ethical approval}

All procedures performed in studies involving human participants were in accordance with the ethical standards of the institutional and/or national research committee and with the 1964 Helsinki declaration and its later amendments or comparable ethical standards.

\section{ORCID}

Jermaine S. Ma (iD http://orcid.org/0000-0003-3948-5140

Paul R. Hoard (iD http://orcid.org/0000-0001-9082-5492

\section{References}

Bardakçi, M. 2015. "The Alevi Opening of the AKP Government in Turkey: Walking a Tightrope between Democracy and Identity." Turkish Studies 16 (3): 349-370. doi:10.1080/14683849.2015.1050959.

Çelik, A. B., R. Bilali, and Y. Iqbal. 2017. "Patterns of 'Othering' in Turkey: A Study of Ethnic, Ideological, and Sectarian Polarisation." South European Society and Politics 22 (2): 217-238. doi:10.1080/13608746.2016.1250382.

Bjørnskov, C. 2007. "Determinants of Generalized Trust: A Cross-country Comparison." Public Choice 130: 1-21. doi:10.1007/s11127-006-9069-1.

de Certeau, M., L. Giard, and P. Mayol. 1988. The Practice of Everyday Life, Vol. 2: Living and Cooking. Translated by Timothy J. Tomasik. Minneapolis, MN: University of Minnesota Press.

Delhey, J., and K. Newton. 2005. "Predicting Cross-national Levels of Social Trust: Global Attern or Nordic Exceptionalism?" European Sociological Review 21 (4): 311-327. doi:10.1093/esr/jci022.

Diez Medrano, J. 2013. "Interpersonal Trust." ASEP/JDS. Accessed 8 April 2013. http://www.jdsurvey.net/jds/ jdsurveyMaps.jsp?Idioma $=$ I\&SeccionTexto=0404\&NOID=104

Erder, S. 1996. İstanbul'a Bir Kent Kondu: Ümraniye [A City Happened Upon Istanbul: Ümraniye]. İstanbul: İletişim Yayıncilık A. Ş. 
Erder, S. 1999. "Where Do You Hail From?: Localism and Networks in Istanbul." In Istanbul: Between the Global and the Local, Translated and edited by Ç. Keyder, 161-171. Lanham, MD: Rowman \& Littlefield Publishers.

Erdoğan, A. 2015. Mamak: Tarih ve Kültür Atlası [Mamak: A History and Cultural Atlas], 2 vols. Ankara: Mamak Belediyesi Yayınları.

Ergun, A., and A. Erdemir. 2010. "Negotiating Insider and Outsider Identities in the Field: "Insider" in a Foreign Land; "Outsider" in One's Own Land." Field Methods 22 (1): 16-38. doi:10.1177/1525822X09349919.

Erman, T. 1996. "Women and the Housing Environment: The Experiences of Turkish Migrant Women in Squatter (Gecekondu) and Apartment Housing." Environment and Behavior 28 (6): 764-798. doi:10.1177/ 001391659602800603.

Erman, T. 1997. "Squatter (Gecekondu) Housing versus Apartment Housing: Turkish Rural-to-urban Migrant Residents' Perspectives." Habitat International 21 (1): 91-106. doi:10.1016/S0197-3975(96)00048-3.

Erman, T. 2011. "Understanding The Experiences Of The Politics Of Urbanization In Two Gecekondu (Squatter) Neighborhoods Under Two Urban Regimes: Ethnography In The Urban Periphery Of Ankara, Turkey." Urban Anthropology and Studies of Cultural Systems and World Economic Development 40: 67-108.

Erman, T., and B. Hatiboğlu. 2018. "Gendering Residential Space: From Squatter and Slum Housing to the Apartment Estates in Turkish Renewal Projects." City \& Community 17 (3): 808-834. doi:10.1111/cico.12325.

Frederiksen, M. 2014. "Relational Trust: Outline of a Bourdieusian Theory of Interpersonal Trust." Journal of Trust Research 4 (2): 167-192. doi:10.1080/21515581.2014.966829.

Grimpe, B. 2019. "Attending to the Importance of Context: Trust as a Process in Global Microfinance." Journal of Trust Research 9 (1): 87-109. doi:10.1080/21515581.2019.1566073.

Hardin, R. 2006. Trust. Cambridge, UK: Polity Press.

Kalaycıoğlu, E. 2012. "Political Culture." In The Routledge Handbook of Modern Turkey, edited by M. Heper and S. Sayarı, 171-181. London: Routledge.

Karakayali, N. 2004. "Reading Bourdieu with Adorno: The Limits of Critical Theory and Reflexive Sociology." Sociology 38 (2): 351-368. doi:10.1177/0038038504040869.

Kayaoğlu, A. 2017. "Determinants of Trust in Turkey." European Societies 19 (4): 492-516. doi:10.1080/ 14616696.2016 .1228992$.

Khodyakov, D. 2007. "Trust as A Process: A Three-dimensional Approach." Sociology 41 (1): 115-132. doi:10.1177/ 0038038507072285.

Kuyucu, T., and Ö. Ünsal. 2010. “'Urban Transformation' as State-led Property Transfer: An Analysis of Two Cases of Urban Renewal in Istanbul." Urban Studies 47 (7): 1479-1499. doi:10.1177/0042098009353629.

Luhmann, N. 2000. "Familiarity, Confidence, Trust: Problems and Alternatives." In Trust: Making and Breaking Cooperative Relations, edited by D. Gambetta, 94-107. Oxford: University of Oxford.

McEvily, B. 2011. "Reorganizing the Boundaries of Trust: From Discrete Alternatives to Hybrid Forms." Organization Science 22 (5): 1266-1276. doi:10.1287/orsc.1110.0649.

Miller, A. S., and T. Mitamura. 2003. "Are Surveys on Trust Trustworthy?" Social Psychology Quarterly 66 (1): $62-70$. doi:10.2307/3090141.

Mills, A. 2007. "Gender and Mahalle (Neighborhood) Space in Istanbul." Gender, Place \& Culture 14 (3): $335-354$. doi:10.1080/09663690701324995.

Möllering, G. 2013. "Process Views of Trusting and Crises." In Handbook of Advances in Trust Research, edited by R. Bachmann and A. Zaheer, 285-305. Cheltenham, UK: Edward Elgar.

Nannestad, P. 2008. "What Have We Learned About Generalized Trust, If Anything?" Annual Review of Political Science 11 (1): 413-436. doi:10.1146/annurev.polisci.11.060606.135412.

Öktem, K. 2008. "Being Muslim at the Margins: Alevis and the AKP." Middle East Report 246: 5-7.

Poyraz, B. 2005. "The Turkish State and Alevis: Changing Parameters of an Uneasy Relationship." Middle Eastern Studies 41 (4): 503-516. doi:10.1080/00263200500119233.

Poyraz, U. 2011. Looking at the Urban Transformation Project from the Gecekondu Dwellers' Perspective: The Case of Mamak. Middle East Technical University.

Purcell, B. 2017. "The House Unbound: Refiguring Gender and Domestic Boundaries in Urbanizing Southeast Turkey." City \& Society 29 (1): 14-34. doi:10.1111/ciso.12110.

Shankland, D. 2012. "Islam." In The Routledge Handbook of Modern Turkey, edited by M. Heper and S. Sayarı, $108-115$. London: Routledge.

Six, F., B. Nooteboom, and A. Hoogendoorn. 2010. "Actions that Build Interpersonal Trust: A Relational Signalling Perspective." Review of Social Economy 68 (3): 285-315. doi:10.1080/00346760902756487.

Wasti, S. A., H. H. Tan, and S. E. Erdil. 2011. "Antecedents of Trust across Foci: A Comparative Study of Turkey and China." Management and Organization Review 7 (2): 279-302. doi:10.1111/j.1740-8784.2010.00186.x.

World Values Survey. 2014. "World Values Survey Wave - Time Series: A165. - Most People Can Be Trusted." Accessed 20 April 2016. http://www.worldvaluessurvey.org/WVSOnline.jsp 